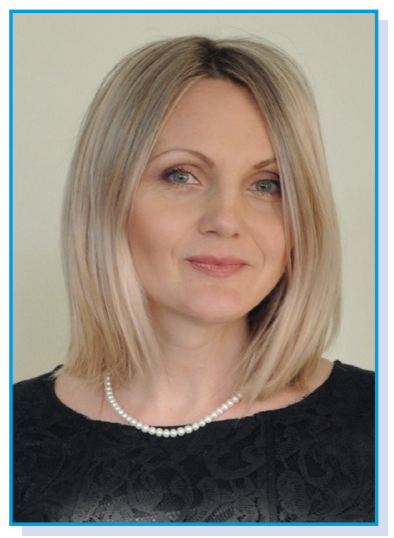

Valentina Novosolova - Candidate of Pedagogical Sciences Senior Researcher at the Department of Ukrainian Language and Literature Studies Institute of Pedagogy of National Academy of Pedagogical Sciences of Ukraine, Kyiv, Ukraine.

A range of scientific interests: methodology of teaching Ukrainian language in general secondary education institutions; a competent approach in teaching Ukrainian; issues of broadcasting culture; theory and practice of school textbooks.

e-mail:ribusya@ukr.net

ORCID iD: https://orcid.org/0000-0003-2987-7888

УДК 372.8: 811.161.2

https://doi.org/10.32405/2411-1317-2019-4-128-134

\title{
A COMPETENTLY DIRECTED TEXTBOOK OF THE UKRAINIAN LANGUAGE AS A MEANS OF FORMATION OF VALUE SYSTEM OF THE LYCEUM STUDENTS
}

The author draws attention to topical issues related to the formation of value orientations, the hierarchy of values in the minds of Lyceum students. These are the problems caused by the modernization of the structure, content and organization of the educational process on the basis of a competence approach, which create new requirements for the creation of a training book, a radical improvement of the functional purpose of the textbook of Ukrainian language. It is noted that the concept of "value orientation" is considered in sociolinguistics. The author describes the state of various scientific researches of modern linguistics, psychology, philosophy, domestic and foreign scientists on the problem of clarifying the concepts of "values", "value orientations", search for ways of forming the moral sphere of life of education seekers. The author presents a textbook "Ukrainian language" for the 11th grade, which aims at forming above all responsible citizens-patriots, who have a valuable attitude to themselves, to their family, society, Ukraine, the world; citizens who understand and accept family, national and universal values. It is substantiated that the effective development of the moral sphere of life of the education seekers, the correct hierarchy of values in their consciousness is facilitated by the process of solving specially selected tasks, the continuity of becoming a student of the subject and key competences, thus creating optimal conditions for assimilation of moral values, the acquisition of moral values, sense of responsibility, spirituality, empathy, readiness for critical entry into society. It has been argued that the speech development of a lyceum student in Ukrainian language lesson will be maximally effective if carried out on condition of identification with one's own people, taking into account value priorities, holistic perception, interconnection of emotional and formal-logical spheres of personality.

Key words: a textbook of Ukrainian language; content; key competences; value orientations, value system.

Problem statement. The process of reforming school language education takes place in the context of the development of Ukrainian civil society and responds to its nowday needs and challenges. In order to establish itself in today's globalized world, we must preserve our values of a world view, embodied primarily by the Ukrainian language and culture, without which the Lyceum student cannot identify and develop as a citizen, a patriot of his country. 
In a civilized society, the main criterion for determining many aspects of life is values. The value system is the main basis for ensuring the certainty and predictability of the actions of the educational recipients, facilitating their adaptation to life changes.

Nowadays, when spiritual and ideological ideals and norms are being transformed, accompanied by the search for moral supports, there is a need to rethink the educational process and reorient the content of a modern textbook. The concept of reforming the "New Ukrainian School" focuses the attention of education seekers on the formation of key and subject competences of students, moving away from traditional methods of knowledge transfer [1]. Therefore, there is the adaptation of the competence-based approach to new strategic directions of educational reform approved in Ukraine's educational territories.

The modernization of the structure, content and organization of the educational process on the basis of a competency approach determines the new requirements for the creation of a training book, a radical improvement of the functional purpose of the textbook of Ukrainian language, which should reflect those methodological innovations that appeared in the teaching of linguistics and practice.

At the stage of transition to the new educational standards, focused on the development of key competences, a balanced, constructive approach to the problem of creating a worthwhile textbook of Ukrainian language is necessary due to the fact that a large part of the existing stock of educational and methodological literature on the implementation of educational content is in conflict with modern approaches to learning the Ukrainian language and needs careful revision.

Changes in the selection of the content of the textbook are due to the transformation of spiritual and ideological values, moral norms and ideals, the development and implementation of competently directed methods. When it comes to the effective transition to competently oriented learning, the introduction into school practice requires the theoretical acquisition of psycholinguists about the communicative orientation of linguistic units. The educational result is determined by the ways and experience of the activity, the values of the student.

In sociolinguistics, the concept of value orientations is viewed through the prism of the use of language in general and of particular linguistic means. Value orientations caused by the educational system determine the motivation of students' behavior and regulate it. Strengthening the value component in the process of learning Ukrainian language will promote the development of a positive attitude to the language and linguistic means in the multilingual world, the orientation of the student to harmonious communication, the formation of a student of linguistic taste and the desire to control and evaluate their own and foreign language, developmental demands to the language activities.

The content of the textbook of Ukrainian language should be aimed at forming holistic ideas about national values: patriotism, love and respect for the Motherland, the people, Ukrainian language, state, national, family virtues, tolerant attitude to every person, who cultivates personality, capable to the cultural interaction in the new historical realities. The educational book should realize the idea of revival of national culture and spirituality, which will contribute to the development of national consciousness, historical memory of the recipients of education

It is impossible to impart to students the idea of Ukrainian cultural identity irrespective of the cultural heritage of other peoples of the world. Assessing the works of Ukrainian artists in the context of world heritage, students form an idea of their own significance.

The analysis of the latest researches and publications. The analysis of the latest researches and publications shows that in modern linguodidactics there is an increased interest of domestic and foreign scientists to the problem of clarification of the essence of the concepts of "values", "value orientations", search for ways of forming the moral sphere of life of education seekers.

The purpose of the article. The purpose of the article is to illustrate the problems of value system formation for applicants of education, as well as to reveal the peculiarities of value orientations by means of the Ukrainian language school textbook for grade 11 (authors N. Golub, O. Goroshkina, V. Novosyolova) [2].

The moral problem of educating the younger generation, the harmonious development of the individual is the center of psychological thought of both the past and the present. The nervous system, 
psychics, personal characteristics of the student quantitatively and qualitatively change throughout his life and are inextricably linked to the educational process. It is a moral factor of the current seeker of education that loses its weight and significance.

One of the stucture of human individuality is the system of semantic relations and values. In the aspect of individuality as a person's identity, sense is the realization of the absolute value of the event and the act and at the same time the subjective experience of that value by the person. The identity of a man is made in relation to the basic values of the social life. The answer to the question: why? involves determining the value attitude that underlies the action, action, activity, all life as a whole.

The meaning of life, expressing a person's life positions and aspirations, depends on his real achievements, his real ability to express himself in life forms. "... The meaning of life, - K. Abulkhanov-Slavska writes - is not only the future, not only the prospect, but also the measure achieved by man, the assessment achieved by his own forces on essential criteria of personality [3, p. 73] ». The formations of individuality include the system of beliefs of the person, which form the basis of her "I", determine actions, judgments, norms of behavior. This system of believes is a source of motivation for moral action.

According to V. Sukhomlinsky, the basic component of values in the humanistic system of education is the moral, so one of the main tasks of the school is to fully reveal the wealth of the intellectual, emotional, moral spheres of the spiritual life of the individual, while at the same time "learning, the process of mastering knowledge should be considered in a wide the plan of moral education [4, p. 472]».

In domestic pedagogical activity and philosophical views of G. Vashchenko, P. Kulish, G. Skovoroda, M. Stelmakhovich, V. Sukhomlinsky, P. Yurkevich is given priority to the spiritual, not the material, in human ontogeny. The Ukrainian philosophy of the heart is based on the Platonic and Christian traditions, defending the free will of man, the value and moral value of human action. P. Yurkevich's writings are dominated by the idea that the search for truth and the goodness is not limited to the efforts of the mind, the goodness is possible as an act of a sincere heart, a sincere soul. P. Yurkevich defends the view of the heart as the center of the spiritual life that determines the essence of the human personality. "The ethical norms of humanity are extremely important: goodness, justice, honesty, humanity, respect for life, mutual assistance, etc. are a way of sensually-psychic reflection and perception by a person of different aspects of life, the responses of the individual psychics to the requests of the outside world. The quality of these reactions is determined by a person's natural or acquired ability to self-identify in the nature and in the society. [5, p. 331]».

The most important tasks of noospheric education include the inculturation of the individual, that is, its introduction into the system of value-meaning and evaluation criteria, the acquisition of historically produced rules, within which the assessment of various phenomena is allowed. Positive thoughts collectively shape the appropriate moral atmosphere in the family, collective, society, and change life for the better. The Ukrainian people are traditionally characterized by a lifestyle filled with positives in every verbal form. For example, in the word "vorizenki" (eng. enemies) the hue of aggression is minimized. The concept of noospheric education involves the transformation of negative problems, moods, efforts into positive ones. [6].

The pedagogical approaches of G. Vashchenko are close to these views. In his opinion, human morality is based on intellectual, strong-willed and sensual factors. The intelligence of the personality ensures the awareness of the obligations, the will helps it to keep the moral principles, and the sensuality provides the evaluation and experience (satisfaction - dissatisfaction) of a person and others' actions. "Sensual" here approaches the concept of "conscience", which provides a person with the ability to control their own behavior [7, p. 63].

In times of difficult current situation in Ukraine, the student needs warmth, attention, moral guidance, vital examples. Given the social manifestations of psychological tension, criticism and frustration, negativity and aggression, the authors of the textbook should form a belief in goodness and peace and bring true and exciting stories to the students' minds. They learn to respect and love native, authentic, Ukrainian. 
O. Vyshnevsky's opinion is correct, which states that "when it comes to morality and moral qualities, formulation of rules, the imaginary structure of moral laws are not as important as how we treat morality [3, p. 32]». Efforts should be made to ensure that the education seeker believes, accepts, and takes the moral rules of conduct as the basis of his or her own life.

Presenting the main material. At each language lesson, the student will become morally and spiritually better, internally richer. It is not enough to teach him how to pronounce, use or spell words correctly, put punctuation marks. An student should know how not to hurt with a word or sentence, support a person, state their position, and at the same time create a sense of responsibility for every word used.

The content and methodological apparatus of the textbook of Ukrainian language for the 11th grade (authors N. Golub, O. Goroshkina, V. Novosyolova) [2] are aimed at forming:

- ability to respect human rights, realize personal responsibility for the fate of the country, the people, think critically, understand the importance of civic participation in the process of solving various social problems;

- patriotic citizens who are valued by their attitude towards themselves, their families, society, Ukraine, and the world;

- ability to achieve educational outcomes - key and substantive competencies that imply developing the skills to apply the knowledge acquired, to form their own attitudes and behavioral norms;

- socialization of students and development of self-confidence, development of activity, initiative, purposefulness, independence, responsibility for the results of their own educational activity.

The textbook values grouped around the basic triad of "Truth", "Goodness" and "Beauty", which accumulate three dimensions of the life of a person: cognition, living according to the laws of morality and the ability to aesthetically evaluate reality. The textbook will encourage the preservation of the past for the sake of the future, to share kindness, to defend freedom, independence, honor, dignity, honesty, loyalty, to use the code of honor and the rules of a wise life that make a person happy.

The innovative nature of the textbook is that it aims to educate citizens who understand and embrace family, national and people values. For example, the students' awareness of charitable work is suggested to be achieved in the following tasks: "Join in several groups to prepare the Workshop of Goodness" project. Check out the international social project Book of Goodness (https://knyga-dobra.blogspot.com/p/50-50.html). Read the project participants' history on the website and write a story about the act that impressed you the most, "Prepare the project "Happiest and the person who gave happiness to the largest number of people", offer your own formula for the happiness of others. "

Authors suggest to think, to feel the state of another person, to sympathize in certain circumstances.

In the content of the textbook, this is realized through texts and methodically appropriate system of tasks and exercises that develop and control the formation of a certain competence.

Teamwork is the basis of many tasks and exercises. Their effective implementation is possible provided the ideas and cooperation of each participant are combined. For example, the task of "Join in teams to prepare a project" Emergency aid to the birds. Draw up and write down a collaboration plan. Find out which birds and where are most commonly affected by cold. What are the dangers for birds at any time? Learn what not to do to avoid harming birds. Where to go for help if you can't handle it yourself? Explore the experiences of people who have rescued the birds» shape students' ability to understand their own personal responsibility for the fate of others, develop critical thinking skills, and understand the importance of civic participation in addressing diverse social issues. Such tasks will teach them to work productively and without conflict in a team, and in the event of misunderstandings, effectively solve them without conflict.

An important structural component of the textbook is the text, which is the main source of cognition and emotional impact, a means of creating communicative situations that underlies the process 
of real communication. By immersing themselves in an imaginary social environment or modeling their own situation, students will be able to feel the effectiveness of the educational results achieved not only within the school, but also to demonstrate one or another competence in a specific situation outside of it. Understanding the situation will contribute to the formation of students' moral believes, a system of views and a positive value attitude to the actions.

To master the skills of directing communication towards the establishment of relations and prevention of conflict situations, it is good and expedient to express greetings, sympathy, proposal, agreement / disagreement. The textbook focuses on enhancing the language genres in the daily practice of teaching Ukrainian in general secondary education.

The textbook contains analytical tasks, such mandatory components of the lesson as motivation, reflection, creative exercises, tasks designed for joint activities in pairs and groups, writing and playing dialogues, finding information with the involvement of various sources, tasks for organizing discussions, project and research activities. In the process of accomplishing such tasks as: "Consider what needs to be done in order for Ukrainians to actively promote themselves and their cultural heritage in the world. Write a comment (3-4 sentences) on this topic", "Write an essay on "It is now becoming clear that everyone is both the cause and the victim of the global environmental crisis". "Create a project on value system, communication culture in electronic communication", "Analyze the work in the lesson. What is your discovery and achievement today? Emphasize what new things you have learned and whether the lesson's material has influenced your plans for the future, "How did the section material affect your attitude to yourself and the world? "," Analyze your activity and its results in the lesson. Answer the question: In what situations will you never argue? What is it worth not starting a dispute about? What controversy is meaningless? When are disputes useful? »Students reflect on their own life position, analyze what they have enriched during each lesson, restore course of action and reasoning throughout the lesson, evaluate their own results, reflect on the importance of the learned information in the lesson for the formation of moral and spiritual values.

Conclusions and prospects for further research. Thus, in a period of drastic educational change, when the modern educator is encouraged to innovate, the value aspect of the educational process becomes particularly important. Exercises, tasks, and questions of the textbook of Ukrainian language form a coherent didactic system that provides for the continuity of students' acquisition of subject and key competences [4]. This approach creates the optimum conditions for a positive attitude of the students, which will contribute to the formation of a correct hierarchy of values in the minds of the students of the Lyceum. According to the place of values in the hierarchy it will develop the personal qualities of the Lyceum students, a sense of responsibility, spirituality, empathy, etc.

This topic opens new horizons in reaching the ultimate goal of forming a system of values for education recipients and needs further development and research. Generalization of the testing and presentation of the results of the experimental verification of the system of exercises and tasks contained in the analyzed textbook will be the subject of our further scientific and practical search.

\section{Використані джерела}

[1] Нова українська школа: концептуальні засади реформування середньої школи, Київ, Україна, 2016. [Електронний pecypc]. Доступно: https://www.kmu.gov.ua/storage/app/media/reforms/ ukrainska-shkola-compressed.pdf. Дата звернення: Вересень, 14, 2019.

[2] Н. Б. Голуб, О. М. Горошкіна, В. І. Новосьолова Українська мова (рівень стандарту) підручник для 11 класу закладів загальної середньої освіти, Київ, Україна: Педагогічна думка, 2019.

[3] К. А. Абульханова-Славская, «Стратегия жизни», Москва, Росия: Мысль, 1991.

[4] В. О. Сухомлинський, Вибрані твори у 5-ти т., Київ, Україна: Рад. школа, 1977, Т. 5.

[5] П. Д. Юркевич, Вибране, Київ, УКраїна: Абрис, 1993.

[6] Н. В.Маслова Ноосферное образование. Научные основы. Концепция. Методология, технология. Москва, Россия: Инст. холододинамики, 2002. 
[7] Г. Ващенко, Виховний ідеал, підруч. для педагогів, виховників, молоді і батьків. Всеукраїнське педагогічне товариство ім. Григорія Ващенка, 4-е вид. Львів, Україна: Камула, 2006.

[8] О. Вишневський, Сучасне українське виховання: педагогічні нариси. Львів, Україна: Львівський обласний інститут освіти; Львівське обласне педагогічне товариство ім. Г. Ващенка, 1996.

\section{References}

[1] Nova ukrainska shkola: kontseptualni zasady reformuvannia serednoi shkoly, Kyiv, Ukraina, 2016. [online].Available: https://www.kmu.gov.ua/storage/app/media/reforms/ukrainska-shkola-compressed. pdf . Data zvernennia: Veresen, 14, 2019.

[2] N. B. Holub, O. M. Horoshkina, V. I. Novosolova Ukrainska mova (riven standartu) pidruchnyk dlia 11 klasu zakladiv zahalnoi serednoi osvity, Kyiv, Ukraina: Pedahohichna dumka, 2019.

[3] K. A. Abulkhanova-Slavskaia, «Stratehyia zhyzny», Moskva, Rosiia: Mыsl, 1991.

[4] V. O. Sukhomlynskyi, Vybrani tvory u 5-ty t., Kyiv, Ukraina: Rad. shkola, 1977, T. 5.

[5] P. D. Yurkevych, Vybrane, Kyiv, UKraina: Abrys, 1993.

[6] N. V.Maslova, Noosfernoe obrazovanye. Nauchnыe osnovы. Kontseptsyia. Metodolohyia, tekhnolohyia. Moskva, Rossyia: Ynst. kholododynamyky, 2002.

[7] H. Vashchenko, Vykhovnyi ideal, pidruch. dlia pedahohiv, vykhovnykiv, molodi i batkiv. Vseukrainske pedahohichne tovarystvo im. Hryhoriia Vashchenka, 4-e vyd. Lviv, Ukraina: Kamula, 2006.

[8] O. Vyshnevskyi, Suchasne ukrainske vykhovannia: pedahohichni narysy. Lviv, Ukraina: Lvivskyi oblasnyi instytut osvity; Lvivske oblasne pedahohichne tovarystvo im. H. Vashchenka, 1996.

Валентина Новосьолова, кандидат педагогічних наук, старший науковий співробітник відділу навчання украӥнської мови та літератури Інституту педагогіки НАПН України.

\section{КОМПЕТЕНТНІСНО СПРЯМОВАНИЙ ПІДРУЧНИК УКРАЇНСЫКОЇ МОВИ ЯК ЗАСІБ ФОРМУВАННЯ ЦІННІСНИХ ОРІЕНТАЦІЙ УЧНІВ ЛІЦЕЮ}

Авторка статті привертає увагу до актуальних питань, пов'язаних із формуванням ціннісних орієнтацій, ієрархії цінностей у свідомості учнів ліцею. Ідеться про ті проблеми, що зумовлені модернізацією структури, змісту й організації освітнього процесу на засадах компетентнісного підходу, і визначають нові вимоги до створення навчальної книжки, докорінного удосконалення функціонального призначення підручника української мови. Відзначається, як поняття «ціннісні орієнтації» розглядають у соціолінгвістиці. Авторка характеризує стан різноаспектних наукових досліджень сучасної лінгводидактики, психології, філософії, вітчизняних і зарубіжних науковців з проблеми з'ясування суті понять «цінності», «ціннісні орієнтації», пошукові шляхів формування моральної сфери життя здобувачів освіти. Авторка презентує підручник «Українська мова» для 11 класу, який спрямований на формування передусім відповідальних громадян-патріотів, яким властиве ціннісне ставлення до себе, родини, суспільства, України, світу; громадян, які розуміють і приймають родинні, національні й загальнолюдські цінності. Обгрунтовано, що ефективному розвиткові моральної сфери життя здобувачів освіти, правильної ієрархії цінностей у свідомості їх сприяє процес розв'язування спеціально дібраних завдань, неперервність становлення в учнів ліцею предметної й ключових компетентностей, завдяки чому створюються оптимальні умови для засвоєння моральних цінностей, становлення особистісних якостей учнів, почуття відповідальності, духовності, емпатії, готовності до критичного входження в соціум. Стверджено, що мовленнєвий розвиток учня ліцею на уроці української мови буде максимально ефективним, якщо здійснюватиметься за умови ідентифікації з власним народом, урахування ціннісних пріоритетів, цілісного світосприймання, взаємозв'язку емотивної та формально-логічної сфер особистості.

Ключові слова: підручник української мови; зміст; ключові компетентності; ціннісні орієнтації, система цінностей. 
Валентина Новосёлова, кандидат педагогических наук, стариий научный сотрудник отдела обучения украинскому языку и литературе Института педагогики НАПН Украинь.

\section{КОМПЕТЕНТНОСТНО НАПРАВЛЕННЫЙ УЧЕБНИК УКРАИНСКОГО ЯЗЫКА КАК СРЕДСТВО ФОРМИРОВАНИЯ ЦЕННОСТНЫХ ОРИЕНТАЦИЙ УЧАЩИХСЯ ЛИЦЕЯ}

Автор статьи обращает внимание на актуальные вопросы, связанные с формированием ценностных ориентаций, иерархией ценностей в сознании учащихся лицея. Речь идет о проблемах, обусловленных модернизацией структуры, содержания и организации образовательного процесса на основе компетентностного подхода, определяющих новые требования к созданию учебной книги, совершенствования функционального назначения учебника украинского языка. Отмечается, как понятие «ценностные ориентации» рассматривают в социолингвистике. Автор характеризует состояние разноаспектных научных исследований современной лингводидактики, психологии, философии, отечественных и зарубежных ученых по проблеме определения сути понятий «ценности», «ценностные ориентации», поиску путей формирования нравственной сферы жизни учащихся. Автор представляет учебник «Украинский язык» для 11 класса, который направлен на формирование прежде всего ответственных граждан-патриотов, которым свойственно ценностное отношение к себе, семье, обществу, Украине, миру; граждан, которые понимают и принимают родственные, национальные и общечеловеческие ценности.

Обосновано, что эффективному развитию нравственной сферы жизни учащихся, правильной иерархии ценностей в их сознании способствует процесс решения специально разработанных задач, непрерывность формирования в учащихся лицея предметной и ключевых компетентностей, благодаря чему создаются оптимальные условия для усвоения нравственных ценностей, развития личностных качеств учащихся, чувства ответственности, духовности, эмпатии, готовности к критическому вхождению в социум. Утверждено, что речевое развитие учащегося лицея на уроке украинского языка будет максимально эффективным, если будет осуществляться при условии идентификации с собственным народом, учетом ценностных приоритетов, целостного мировосприятия, взаимосвязи эмотивной и формально-логической сфер личности.

Ключевые слова: учебник украинского языка; содержание; ключевые компетентности; ценностные ориентации, система ценностей. 